\title{
MLH1 -93G>A and I219V polymorphisms are susceptible to increased risk of sporadic colorectal cancer in a Turkish population
}

\author{
Ezgi Öztaș ${ }^{1, *}$, Umay Çilingir ${ }^{1}$, Ahmet Akyüz', Hakan T. Yanar², Gül Özhan \\ 'Department of Pharmaceutical Toxicology, Faculty of Pharmacy, Istanbul University, 34116 Istanbul, Turkey \\ ${ }^{2}$ Department of General Surgery, Faculty of Medicine, İstanbul University, 34093 İstanbul, Turkey
}

Cite this article as: Öztaș E, Cilingir U, Akyüz A, Yanar HT, Özhan G (2017). MLH1 -93G>A and I219V polymorphisms are susceptible to increased risk of sporadic colorectal cancer in a Turkish population. Istanbul J Pharm 47 (2): 63-67.

\begin{abstract}
Colorectal cancer (CRC) comprises approximately $10 \%$ of all cancers and is a major cause of cancer-related morbidity and mortality despite current diagnostic and treatment improvements. DNA damage and altered DNA replication through the deregulation of related genes cause genomic instability in sporadic CRC. DNA repair is very complex; many factors play a role to ensure that the restoration of errors occurs during the transfer of genetic material. MutL homolog 1 (MLH1) is one of the vital DNA repair genes responsible for genomic stability. Together with environmental factors, the genetic background may be associated with CRC development; thus, genetic polymorphisms are considered as risk factors. The present prospective casecontrol study aimed to determine the association between $93 \mathrm{G}>\mathrm{A}$ and $1219 \mathrm{~V}$ polymorphisms of MLH1 and CRC susceptibility in a Turkish population. The genotyping of 158 patients and 164 age- and sex-matched controls was performed by polymerase chain reaction-restriction fragment length polymorphism. Two variants, 93G $>\mathrm{A}$ and $1219 \mathrm{~V}$, were associated with an increased risk of $C R C$. Individuals with $A$ allele of $93 \mathrm{G}>\mathrm{A}$ had an approximately 2 -fold risk (OR: 1.92, 95\% $\mathrm{Cl}: 1.22-3.04 ; \mathrm{p}<0.01$ ) and those with $\mathrm{G}$ allele of $\mathrm{I} 219 \mathrm{~V}$ had an approximately 3 -fold risk (OR: $2.82,95 \% \mathrm{Cl}: 1.76-4.52 ; \mathrm{p}<0.01$ ) of developing CRC. Our results provide novel information for understanding the influence of $M L H 1$ on CRC risk in the Turkish population; however, further studies with a larger number of participants are required.
\end{abstract}

Keywords: MLH1 polymorphism, colorectal cancer, PCR-RFLP

\section{INTRODUCTION}

Colorectal cancer (CRC), for many years, is in the third place of all cancers both in men and women, and is a major cause of cancer-related morbidity and mortality (Berndt et al. 2007, Siegel et al. 2015). Genetic background covers a great position in the complexity of the CRC aetiology; and together with environmental factors, CRC incidence is varied among different populations (Aykan 2000, Haggar and Boushey 2009; Huxley et al. 2009). Recently, several pathways contributed to cancer development have been identified. It is well known that genomic instability is the origin triggers as well as other cancer-related mechanisms in hereditary cancers. However, in sporadic cancers, genomic instability is a consequence of DNA damage and alteration in DNA replication due to deregulation of the related genes in addition with impaired DNA repair (Anderson 2001, Negrini et al. 2010). Therefore, DNA repair mechanisms play crucial role in cancer prevention through maintaining genomic stability and DNA integrity (Abbas et al. 2013).

DNA repair is a very complex process in which many factors play a role together starting from the identification of the damaged region to post-replication. Mismatch repair (MMR) is one of the major mechanisms in DNA repair and MMR genes play 
a key role in fixing several errors such as insertions and deletions that occurred during the replication (Milanowska et al. 2010). MutL Homolog 1 (MLH1), a member of MMR genes, has been suggested to be associated with both hereditary and sporadic CRCs through either genetic polymorphisms or epigenetic regulations (Richter et al. 2014, Zhang et al. 2016, Savio et al. 2017). For over a decade, the association between MLH1 polymorphisms and CRC has been investigated; however, a definite conclusion has not been agreed (Burmester et al. 2004, Yu et al. 2006, Rajender et al. 2010, Valentin et al. 2012). It should be considered that conflicted results may be due to diversities between populations as well as numbers of the participants; therefore, further studies conducted with different populations were needed. In this present study, effects of MLH1 polymorphisms on sporadic CRC susceptibility were evaluated in a Turkish population for the first time.

\section{MATERIALS AND METHODS}

A prospective case-control study was conducted with Turkish participants from Hospital of İstanbul University between 2011 and 2016. Adenocarcinoma of the colon or rectum was confirmed by routine laboratory and histological evaluations in 158 participants. Ethnic-age-sex-matched controls who had no history of any type of cancer were selected randomly from various divisions of the hospital and 164 participants were evaluated. All participants were provided informed consent. Study was conducted in accordance with the Helsinki
Declaration and was approved by the ethics committee of İstanbul University (2016/1238).

Venous blood was collected into vacutainer EDTA tubes and within the same day genomic DNA was extracted by standard phenol-chloroform extraction protocol. DNA concentrations were measured by Take3 Plate on Epoch microplate spectrophotometer (BioTek, Winooski, USA) and diluted as appropriate. Genotyping of $-93 \mathrm{G}>\mathrm{A}$ and $1219 \mathrm{~V}$ was performed by polymerase chain reaction-restriction fragment length polymorphism (PCR-RFLP) method. Primers were synthesized by Sentromer DNA Technologies Laboratory (Istanbul, Turkey) and restriction enzymes were purchased by New England Biolabs (Hitchin, England). All other chemicals and plastic-ware were obtained from Sigma-Aldrich (St. Louis, Missouri, USA), Merck (Darmstadt, Germany) and Isolab $\mathrm{GmbH}$ (İstanbul, Turkey) as suitable grade for molecular research. Amplification and restriction conditions were shown in Table 1. Restriction products were identified on $2 \%$ agarose gels stained with ethidium bromide by a UV transilluminator. In each run, controls of known wild-type, heterozygous, and mutant genotype were included to check the accuracy that yielded $100 \%$ concordance.

All statistical analyses were carried out by using Statistical Package for Social Sciences (SPSS, version 21.0) and GraphPad Prism (version 5.0a) programs. Hardy-Weinberg equilibrium was tested by using chi-square $\left(X^{2}\right)$. The dominant model

Table 1. Amplification and restriction conditions of studied SNPs

\begin{tabular}{|c|c|c|c|c|}
\hline SNPs & Primers & Annealing & Restriction & Fragment length (bp) \\
\hline$-93 G>A$ & F:5'-ACAgAgTTgAgAAATTTgACT-3' & & Pvull-HF & W/W: 180, 207 \\
\hline (rs1800734) & R:5'-ATCTCTTTgATAgCATTAgCT-3' & $51.1^{\circ} \mathrm{C}$ & $37^{\circ} \mathrm{C} 10 \mathrm{~min}$ & $\begin{array}{c}\text { W/M: } 180,207,387 \\
\text { M/M: } 387\end{array}$ \\
\hline I219V & F:5'-TCAgTACACAATgCAggCAT-3' & & $\mathrm{Bccl}$ & W/W: 345,107 \\
\hline (rs1799977) & R:5'-TACgTgAAATAAgAACTCCAT-3' & $57.8^{\circ} \mathrm{C}$ & $37^{\circ} \mathrm{C} 60 \mathrm{~min}$ & $\begin{array}{c}\text { W/M: } 452,345,107 \\
M / M: 452\end{array}$ \\
\hline
\end{tabular}

Table 2. Genotype distributions of MLH1 polymorphisms among sporadic CRC cases and healthy controls

\begin{tabular}{|c|c|c|c|c|c|}
\hline SNPs & Genotypes & $\begin{array}{c}\text { Frequencies } \\
\text { Cases }(n=158, \%)\end{array}$ & Controls ( $n=164, \%)$ & OR (95\% CI) & $p$ \\
\hline$-93 G>A$ & GG & $50(31.6)$ & $75(48.1)$ & GG vs. any $A$ & $p<0.01$ \\
\hline (rs1800734) & $\begin{array}{l}\text { GA } \\
\text { AA }\end{array}$ & $\begin{array}{l}60(37.9) \\
48(30.5)\end{array}$ & $\begin{array}{c}66(42.3) \\
15(9.6)\end{array}$ & $1.92(1.22-3.04)$ & \\
\hline MAF & & 0.494 & 0.307 & & \\
\hline I219V & AA & $42(28.5)$ & $87(53.1)$ & AA vs. any $G$ & $p<0.01$ \\
\hline \multirow[t]{2}{*}{ (rs1799977) } & $A G$ & $72(48.9)$ & $72(43.9)$ & $2.82(1.76-4.52)$ & \\
\hline & GG & $33(22.6)$ & $5(4.8)$ & & \\
\hline MAF & & 0.469 & 0.250 & & \\
\hline
\end{tabular}


which is the wild type was chosen as reference group was used in genotyping analysis. Data comparisons were done by using Fisher's exact test; and, the odds ratios (ORs) and 95\% confidence intervals (Cls) were estimated to evaluate the association between cases and controls. A two-tailed $p<0.05$ was considered to indicate a statistically significant difference.

\section{RESULTS}

MLH1 -93G >A and I219V polymorphisms were evaluated for the sporadic CRC susceptibility with the Turkish participants. All samples were genotyped with at least $93.1 \%$ successful rate and 100\% concordance. There were no significant differences between cases and controls for age and sex, and genotype distribution was found to be consistent with the Hardy-Weinberg equilibrium ( $p>0.05$ ) suggesting that the studied population was unbiased.

Genotype distributions of studied SNPs were summarized in Table 2. The $-93 \mathrm{G}>\mathrm{A}$ and $1219 \mathrm{~V}$ minor allele frequencies were 0.494 and 0.469 in cases whereas 0.307 and 0.250 in controls, respectively. The variant alleles of each SNP were compared between cases and controls based on the dominant model to estimate the risk of CRC. Individuals with $A$ allele of $-93 \mathrm{G}>\mathrm{A}$ had about 2-fold ( $\mathrm{OR}=1.92 ; 95 \% \mathrm{Cl}=1.22-3.04 ; p<0.01)$ and $\mathrm{G}$ allele of I219V had about 3-fold (OR=2.82; 95\% Cl=1.76-4.52; $\mathrm{p}<0.01$ ) risk of developing sporadic $C R C$.

\section{DISCUSSION}

MMR system is responsible for impeccable DNA replication. As a result of inability to correct the errors during DNA replication, the length of microsatellite alleles changes due to the insertion and deletion of repetitive units in DNA. MLH1, a member of MMR genes, is one of the most studied genes due to its crucial role in maintaining the genomic stability through DNA repair. Genetic polymorphisms alone or together with epigenetic regulations in MLH1 may cause microsatellite instability (MSI); thus may alter the cancer susceptibility (Berndt et al. 2007, Curtin 2012).

Because of the genomic instability is the initial factor in hereditary cancers, many researchers focused on the role of MLH1 polymorphisms in Lynch Syndrome (LS) and/or Hereditary Nonpolyposis Colorectal Cancer (HNPCC) susceptibility. Rajender et al. (2010) reported that MLH1 R659X (1975C>T) mutation is associated with HNPCC and 655A $>\mathrm{G}$ locus is highly polymorphic whereas $1219 \mathrm{~V}$ has no influence in Indian population. Valentin et al. (2012) found that $51.61 \%$ of the Southern Americans with LS carry Val allele of MLH1 I219V; however, Val allele is not associated with CRC development. Colorectal and prostate adenocarcinomas coexist in the vast majority of HNPCC patients. Burmester et al. (2004) reported that MLH1 1219V (A>G) variant is associated with prostate cancer; however, Fredriksson et al. (2006) found any association. Additionally, Fan et al. (2007) conducted a study with both hereditary and sporadic CRC patients in East Asia, and reported that MLH1 V384D (T>A) and Q701K (C>A) polymorphisms might increase the risk. Also, Ohsawa et al. (2009) and Peng et al. (2015) reported that MLH1 V384D polymorphism might be associated with sporadic CRC in Japanese and Chinese populations, respectively.

It is well known that, MSI is occurred in the half of the LS patients (Tantoğlu 2012). Campbell et al. (2009) suggested MSI-positive patients carrying -93A allele has 2-fold increased risk of colon cancer while there is no association between MSI-negative patients. However, in the same study, it was found that -93A allele is associated with smoking in MSInegative patients. Additionally, Whiffin et al. (2011) reported that -93G $>$ A polymorphism is associated with increased risk of both MSI-positive CRC and overall CRC.

Besides polymorphic changes, epigenetic regulations in MLH1 may alter the risk of CRC. Mrkonjic et al. (2010) suggested that -93G>A polymorphism is associated with CRC in MSI-positive patients due to protein loss through methylation in the MLH1 promotor region. Similarly, Kim et al. (2004) reported that $1219 \mathrm{~V}$ polymorphism and MLH1 protein expression is correlated; however, Santibanez Koref et al. (2010) did not found any association between $1219 \mathrm{~V}$ polymorphism and MLH1 methylation in CRC patients.

Our results suggested that both $-93 \mathrm{G}>\mathrm{A}$ and I219V variants are associated with 2-fold and 3-fold increased risk of sporadic CRC in Turkish population, respectively. Similarly, Allan et al. (2008) reported that $-93 \mathrm{~A}$ variant is increased the risk of CRC approximately 3-fold; and Wang et al. (2012) suggested that -93G>A polymorphisms increased the risk of MSI-positive CRC. In addition, Milanizadeh et al. (2013) suggested that MLH1 I219V polymorphism is associated with sporadic CRC in East Asia.

On the other hand, Yu et al. (2006) reported that MLH1 $-93 \mathrm{G}>\mathrm{A}$ polymorphism is not associated with colorectal adenoma and/or hyperplastic polyposis; however, -93A variant increased the 2-fold in the risk of adenoma and 10-fold in the risk of hyperplastic polyposis 10-fold among smokers. Similarly, Liu et al. (1995) and Peng et al. (2015) suggested that MLH1-93G > A, 1219V and G39E polymorphisms were not associated with neither adenomatous polyps nor colorectal polyps. Also, Picelli et al. (2010) found that MLH1 I219V polymorphism increased the risk of CRC risk; however, the association did not reach statistical significance.

\section{CONCLUSION}

The data is the first in understanding the influence of MLH1 on CRC risk in Turkish population, and suggested that $-93 \mathrm{G}>\mathrm{A}$ and $1219 \mathrm{~V}$ polymorphisms might be associated with sporadic CRC susceptibility. However, it should be considered that conflicted results may be due to diversities between populations as well as numbers of the participants; therefore, further studies conducted with different populations are needed. 


\section{Acknowledgement}

This project was supported by Research Fund of İstanbul University (Project No. TLO-2016-23421). The authors thank to all participants who volunteered.

\section{REFERENCES}

- Abbas T, Keaton MA, Dutta A (2013). Genomic instability in cancer. Cold Spring Harb Perspect Bio/ 5: a012914. [CrossRef]

- Allan JM, Shorto J, Adlard J, Bury J, Coggins R, George R, Katory M, Quirke P, Richman S, Scott D, Scott K, Seymour M, Travis LB, Worrillow LJ, Bishop DT, Cox A (2008). MLH1 - 93G> A promoter polymorphism and risk of mismatch repair deficient colorectal cancer. Int J Cancer 123: 2456-2459. [CrossRef]

- Anderson GR (2001). Genomic instability in cancer. Curr Sci 81 : 501-507. [CrossRef]

- Aykan F (2000). Kolorektal Kanserler. In: Topuz E, Aydiner A and Karadeniz AN (eds.). Klinik Onkoloji, İstanbul Üniversitesi, Onkoloji Enstitüsü Yayınları, İstanbul, pp 90-95.

- Berndt SI, Platz EA, Fallin MD, Thuita LW, Hoffman SC, Helzlsouer KJ (2007). Mismatch repair polymorphisms and the risk of colorectal cancer. Int J Cancer 120: 1548-1554. [CrossRef]

- Burmester JK, Suarez BK, Lin JH, Jin CH, Miller RD, Zhang KQ, Salzman SA, Reding DJ, Catalona WJ (2004). Analysis of candidate genes for prostate cancer. Hum Hered 57: 172-178. [CrossRef]

- Campbell PT, Curtin K, Ulrich CM, Samowitz WS, Bigler J, Velicer CM, Slattery ML (2009). Mismatch repair polymorphisms and risk of colon cancer, tumour microsatellite instability and interactions with lifestyle factors. Gut 58: 661-667. [CrossRef]

- Curtin NJ (2012). DNA repair dysregulation from cancer driver to therapeutic target. Nat Rev Cancer 12: 801-817. [CrossRef]

- $\quad$ Fan Y, Wang W, Zhu M, Zhou J, Peng J, Xu L, Hua Z, Gao X, Wang $Y$ (2007). Analysis of hMLH1 missense mutations in East Asian patients with suspected hereditary nonpolyposis colorectal cancer. Clin Cancer Res 13: 7515-7521. [CrossRef]

- $\quad$ Fredriksson H, Ikonen T, Autio V, Matikainen MP, Helin HJ, Tammela TLJ, Koivisto PA, Schleutker J (2006). Identification of germline MLH1 alterations in familial prostate cancer. Eur J Cancer $\mathbf{4 2}$ : 2802-2806. [CrossRef]

- Haggar FA and Boushey RP (2009). Colorectal cancer epidemiology: incidence, mortality, survival, and risk factors. Clin Colon Rectal Surg 22: 191-197. [CrossRef]

- Huxley RR, Ansary-Moghaddam A, Clifton P, Czernichow S, Parr CL, Woodward M (2009). The impact of dietary and lifestyle risk factors on risk of colorectal cancer: a quantitative overview of the epidemiological evidence. Int J Cancer 125: 71-180. [CrossRef]

- Kim JC, Roh SA, Koo KH, In HK, Kim HC, Chang SY, Lee KH, Kim JS, Lee HI, Bodmer WF (2004). Genotyping possible polymorphic variants of human mismatch repair genes in healthy Korean individuals and sporadic colorectal cancer patients. Fam Cancer 3 129-137. [CrossRef]

- Liu B, Nicolaides NC, Markowitz S, Willson JK, Parsons RE, Jen J, Papadopolous N, Peltomaki P, de la Chapelle A, Hamilton SR, Kinzler KW, Vogelstein B (1995). Mismatch repair gene defects in sporadic colorectal cancers with microsatellite instability. Nat Genet 9: 48-55. [CrossRef]

- Milanizadeh S, Khanyaghma M, Haghighi MM, Mohebbi S, Damavand B, Almasi S, Azimzadeh P, Zali M (2013). Molecular analysis of imperative polymorphisms of MLH1 gene in sporadic colorectal cancer. Cancer Biomark 13: 427-432. [CrossRef]
- Milanowska K, Krwawicz J, Papaj G, Kosinski J, Poleszak K, Lesiak J, Osinska E, Rother K, Bujnicki JM (2010). REPAIRtoire-a database of DNA repairs pathways. Nucleic Acids Res 39: 788-792. [CrossRef]

- Mrkonjic M, Roslin NM, Greenwood CM, Raptis S, Pollett A, Laird PW, Thibodeau SN (2010). Specific variants in the MLH1 gene region may drive DNA methylation, loss of protein expression, and MSI-H colorectal cancer. PLoS One 5: e13314. [CrossRef] Negrini S, Gorgoulis VG, Halazonetis TD (2010). Genomic instability-an evolving hallmark of cancer. Nat Rev Mol Cell Biol 11 220-228. [CrossRef]

- $\quad$ Ohsawa T, Sahara T, Muramatsu S, Nishimura Y, Yathuoka T, Tanaka Y, Yamaguchi K, Ishida H, Akagi K (2009). Colorectal cancer susceptibility associated with the hMLH1 V384D variant. Mol Med Rep 2: 887-891.

- $\quad$ Peng HX, Xu X, Yang R, Chu YM, Yang DM, Xu Y, Zhou FL, Ma WZ, Zhang XJ, Guan M, Yang ZH, Jin ZD (2015). Molecular analysis of MLH1 variants in Chinese sporadic colorectal cancer patients. Genet Mol Res doi: 10.4238/gmr.15027689. [CrossRef]

- $\quad$ Picelli S, Zajac P, Zhou XL, Edler D, Lenander C, Dalen J, Hjern F, Lundgvist N, Lindforss $U$, Pahlman L, Smedh K, Törngvist A, Holm J, Janson M, Andersson M, Ekelund S, Olsson L, Lundeberg J, Lindblom A (2010). Common variants in human CRC genes as low-risk alleles. Eur J Cancer 46: 1041-1048. [CrossRef]

- Rajender S, Pooja S, Kranthi Kumar MV, Karwasra R, Singh L, Thangaraj K (2010). R659X mutation in the MLH1 gene in hereditary nonpolyposis colorectal cancer (HNPCC) in an Indian extended family. Indian J Med Res 131: 64-70.

Richter JM, Pino MS, Austin TR, Campbell E, Szymonifka J, Russo AL, Hong TS, Borger D, lafrate AJ, Chung DC (2014). Genetic mechanisms in interval colon cancers. Dig Dis Sci 59: 22552263. [CrossRef]

- Santibanez Koref M, Wilson V, Cartwright N, Cunnington MS, Mathers JC, Bishop DT, Curtis A, Dunlop MG, Burn J (2010). MLH1 Differential allelic expression in mutation carriers and controls. Ann Hum Genet 74: 479-488. [CrossRef]

- Savio AJ, Mrkonjic M, Lemire M, Gallinger S, Knight JA, Bapat B (2017). The dynamic DNA methylation landscape of the mutL homolog 1 shore is altered by MLH1 -93G> A polymorphism in normal tissues and colorectal cancer. Clin Epigenetics 9: 26-39. [CrossRef]

Siegel RL, Miller KD, Jemal A (2015). Cancer statistics, 2015. CA Cancer J Clin 65: 5-29. [CrossRef]

Tantoğlu U (2012). Herediter non polipozis kolorektal kanser, ailesel kolorektal kanser ve sporadik kolorektal kanser hastalarının soyağacı, mismatch repair gen mutasyonuna bağlı mikrosatellit instabilite oranlarının karşılaştıııması. Ankara Üniversitesi, Tıp Fakültesi, Tıpta Uzmanlık Tezi, Ankara.

- Valentin MD, Da Silva FC, Santos EMM, Da Silva AD, Ferreira FO, Junior SA, Gomy I, Vaccaro C, Redal MA, Valle AD,Sarroca C, Rasmussen LJ, Carraro DM, Rossi BM (2012). Evaluation of MLH1 $1219 \mathrm{~V}$ polymorphism in unrelated South American individuals suspected of having Lynch syndrome. Anticancer Res 32: 43474351.

- $\quad$ Wang T, Liu Y, Sima L, Shi L, Wang Z, Ni C, Zhang Z, Wang M (2012). Association between MLH1 -93G> a polymorphism and risk of colorectal cancer. PLoS one 7: e50449. [CrossRef] 
- Whiffin N, Broderick P, Lubbe SJ, Pittman AM, Peneger S, Chandler I, Houlston RS (2011). MLH1 -93G> A is a risk factor for MSI colorectal cancer. Carcinogenesis 32: 1157-1161. [CrossRef]

- Yu JH, Bigler J, Whitton J, Potter JD, Ulrich CM (2006). Mismatch repair polymorphisms and colorectal polyps: hMLH1-93G> A variant modifies risk associated with smoking. Am J Gastroentero/ 101: 1313-1319. [CrossRef]

- $\quad$ Zhang LL, Tang XJ, Wang XY, Zhu YW, Peng XB, Gong L (2016). A promoter polymorphism in the hMLH1 gene (-93G/A) associated with sporadic colorectal cancer. Oncol Lett 12: 4035-4040. [CrossRef] 